\title{
Simulated climate variability in the region of Rapa Nui during the last millennium
}

\author{
C. Junk ${ }^{1}$ and M. Claussen ${ }^{1,2}$ \\ ${ }^{1}$ Meteorological Institute, University Hamburg, KlimaCampus, Hamburg, Germany \\ ${ }^{2}$ Max Planck Institute for Meteorology, KlimaCampus, Hamburg, Germany \\ Received: 5 January 2011 - Published in Clim. Past Discuss.: 26 January 2011 \\ Revised: 26 April 2011 - Accepted: 10 May 2011 - Published: 6 June 2011
}

\begin{abstract}
Rapa Nui, an isolated island in the Southeast Pacific, was settled by the Polynesians most likely around $1200 \mathrm{AD}$ and was discovered by the Europeans in $1722 \mathrm{AD}$. While the Polynesians presumably found a profuse palm woodland on Rapa Nui, the Europeans faced a landscape dominated by grassland. Scientists have examined potential anthropogenic, biological and climatic induced vegetation changes on Rapa Nui. Here, we analyse observational climate data for the last decades and climate model results for the period 800-1750 AD to explore the potential for a climatic-induced vegetation change. A direct influence of the ENSO phenomenon on the climatic parameters of Rapa Nui could not be found in the model simulations. Furthermore, strong climatic trends from a warm Medieval Period to a Little Ice Age or rapid climatic fluctuations due to large volcanic eruptions were not verifiable for the Rapa Nui region, although they are detectable in the simulations for many regions world wide. Hence, we tentatively conclude that largescale climate changes in the oceanic region around Rapa Nui might be too small to explain strong vegetation changes on the island over the last millennium.
\end{abstract}

\section{Introduction}

Easter Island (in Polynesian language: Rapa Nui) is located at $27^{\circ} 9^{\prime} \mathrm{S}$ and $109^{\circ} 26^{\prime} \mathrm{W}$ in the Southeast Pacific consisting mainly of three extinct volcanoes covering an area of $166 \mathrm{~km}^{2}$. When the Europeans arrived at the isolated island in $1722 \mathrm{AD}$, Rapa Nui's landscape was dominated by grassland; in contrast, at the time of the Polynesian settlement

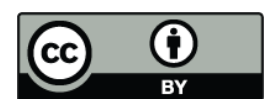

Correspondence to: C. Junk (constantin.junk@zmaw.de) the landscape was presumably covered with palm trees and shrubs, combined with grasses (Flenley et al., 1991; Mieth and Bork, 2005).

Although there are studies suggesting an early colonization of Rapa Nui around $800 \mathrm{AD}$ or even earlier (MartinssonWallin and Crockford, 2001; Mieth and Bork, 2005; amongst others), recent studies indicate that the colonization took place most likely around $1200 \mathrm{AD}$ (Hunt and Lipo, 2006; Wilmshurst et al., 2011). The ancient palm on Rapa Nui was congeneric with the Chilean wine palm (Jubaea Chilensis) known for its sweet sap and edible nuts, and for being frost and salt resistant, but slow growing and producing first flowers when 40 to 60 years old (Flenley and Bahn, 2003). The potential causes for the change from a vegetation which was dominated by palm trees to mainly grass dominated vegetation led to a controversial discussion about the causes of Rapa Nui's vegetation decline.

A detailed sediment-stratigraphic analysis on Poike Peninsula located in the eastern part of Rapa Nui revealed a charcoal layer which covers the old surface of the garden and the palm soil (Mieth and Bork, 2006). In this layer, Mieth and Bork found several carbonized fossil nuts which were dated using the radiocarbon dating method. The authors assume that the Polynesians cleared the woodland by slashing and burning between 1250-1450 AD. The arguments that the aborigine population deforested the island before the first Europeans arrived are also provided by Flenley and King (1984), Flenley and Bahn (2003) and Rolett and Diamond (2004) amongst others. Furthermore, the Polynesian rat (Rattus exulans) might have played a significant role in Rapa Nui's vegetation change (Flenley et al., 1991; Hunt, 2006). Hunt (2006) hypothesizes that the Polynesian rat, which was brought on the canoes with the first Polynesians, could have played a major role in the deforestation of Rapa Nui by

Published by Copernicus Publications on behalf of the European Geosciences Union. 
consuming the palm seeds and preventing palm trees from regeneration. He argues that the role of rats has often been underestimated.

In recent studies, Mann et al. (2008) and Saez et al. (2009) provide a detailed sedimentological and geochemical study of the Raraku Lake sediments to give new insights into the environmental and climate evolution of Rapa Nui during the last millennia. According to Saez et al. (2009), the lake sedimentary record from 34 to 17.3 cal kyr BP supports a scenario of cooler and wetter conditions along with a reduced vegetation cover. A depositional hiatus in the sediments of Rano Raraku between 3990 and 1180 cal yr BP (Mann et al., 2008) and between 4200 and 800 cal yr BP (Saez et al., 2009) suggests that a drought occurred during these periods. This gives rise to a hypothesis according to which climatic fluctuations caused or provided the decline of the palm woodland in prehistoric times. Orliac and Orliac (1997) analysed the fuel in earthen ovens and showed that there was a sudden switch from wood to grasses in the mid-17th century. The authors hypothesize that this indicates a sudden climatic fluctuation such as a severe drought due to the ENSO (El Niño/Southern Oscillation) phenomenon. However, the analysis of climate variability in the Southeast Pacific between 1985-1993 AD did not support the hypothesis of significant ENSO-related inter-annual climate variability at Rapa Nui (MacIntyre, 2001a,b). Similar to these studies, the effects of recent El Niño and La Niña events between 1950 and 2000 AD were explored by Genz and Hunt (2003). An effect of the ENSO phenomenon on the present climate of Rapa Nui could not be found. Another assumption is that the socalled "AD 1300 event" - taken as the transition between the Medieval Warm Period (MWP) and the Little Ice Age (LIA) in this region - caused the vegetation change on Rapa Nui due to uncommonly heavy precipitation associated with rapid cooling (Nunn, 2000). Reconstructions for the central Pacific, however, suggest that the MWP was cool and dry and the Little Ice Age was comparatively warm and relatively wet (Allen, 2006). Numerical experiments with the coupled Pacific ocean-atmosphere Zebiak-Cane model support paleoclimate evidence of an El Niño-like state in the tropical Pacific during the LIA and a La Niña-like state during the MWP (Mann et al., 2005).

In this paper, we explore the possibility of a climaticinduced vegetation change. Therefore, we reassess the climatic conditions on Rapa Nui in the last decades by analysing observational data for the years 1950-2000 AD and satellite data from the HOAPS-3 (Hamburg Ocean Atmosphere Parameters and Fluxes from Satellite Data) precipitation climatology. We then analyse the climate variability in the Rapa Nui region from recent simulations with global climate models for the period 800-1750 AD. Finally, we use the BIOME 1.0 model by Prentice et al. (1992) to tentatively explore potential changes in plant functional types on Rapa Nui that might be triggered by the simulated climate changes.

\section{Analysis of observational data}

To reassess the climatic conditions on Rapa Nui - particularly for testing model results to be explored below -, we have analysed timeseries of monthly rainfall and monthly mean temperature data from Hanga Roa in the southwest of Rapa Nui (Genz and Hunt, 2003). The data indicates a weak annual cycle of monthly mean temperature (between 18.0 $23.8^{\circ} \mathrm{C}$ ) and a humid island's climate (total annual precipitation $P_{\mathrm{obs}} \sim 1110 \mathrm{~mm} \mathrm{yr}^{-1}$, approximately). Climate variations are small presumably because Rapa Nui lies in the Southeast Pacific at the edge of the subtropical gyre which barely shifts during the year. The relatively constant position of the subtropical gyre is due to the small seasonal displacement of the ITCZ (Inter Tropical Convergence Zone) over the Pacific.

To account for the humid climate on Rapa Nui, we assume two effects to be relevant. First, the island effect which includes effects due to the land-sea breeze and convection induced by the orography of Rapa Nui. Second, the interplay of the SPCZ (South Pacific Convergence Zone), the subtropical gyre and the westerly storm tracks centered at $34^{\circ} \mathrm{S}$ (Saez et al., 2009). According to Vincent (1993), the SPCZ is an extended and persistent cloud band which axis stretches from New Guinea east-southeastward to about $30^{\circ} \mathrm{S}$ and $120^{\circ} \mathrm{W}$. To investigate the effect of the SPCZ on the climate of Rapa Nui, we analysed the precipitation climatology between the years 1987-2005 from HOAPS-3 (Andersson et al., 2007). The dataset from HOAPS-3 provides a spatial resolution of $0.5^{\circ}$ on a global grid. Figure 1 (top) shows that Rapa Nui lies on the verge of the SPCZ with precipitation rates of roughly $2 \mathrm{~mm} \mathrm{~d}^{-1}\left(730 \mathrm{~mm} \mathrm{yr}^{-1}\right)$. Because the dataset from HOAPS3 explicitly excludes land areas and, hence, does not include topographic effects, we tentatively attribute the difference between precipitation measured at Hanga Roa and estimated from HOAPS-3 to the island effect and uncertainties in the HOAPS-3 climatology.

To assess the uncertainty, Andersson et al. (2011) compare the precipitation climatology of HOAPS-3 with other climatologies like the atmospheric reanalysis dataset ERA-INTERIM, the satellite-derived product GPCP V2 and the TRMM 3B43 product. Around Rapa Nui, the ERA-INTERIM precipitation climatology is $\sim 0.12 \mathrm{~mm} \mathrm{~d}^{-1}$ (6\%) higher compared to HOAPS-3 precipitation while TRMM 3B43 (GPCP V2) precipitation is $\sim 0.36 \mathrm{~mm} \mathrm{~d}^{-1}$ or $18 \%(\sim 0.14 \mathrm{~mm} / \mathrm{d}$ or $7 \%)$ lower. Since the differences of the precipitation rates in the HOAPS- 3 climatology are relatively small compared to the ERA-INTERIM, GPCP V2 and TRMM 3B43 climatology, we think that the HOAPS-3 climatology is useful for the comparison with simulated rainfall around Rapa Nui. Moreover, HOAPS-3 is the only precipitation climatology which is consistently derived from the same type of satellite instrument. 

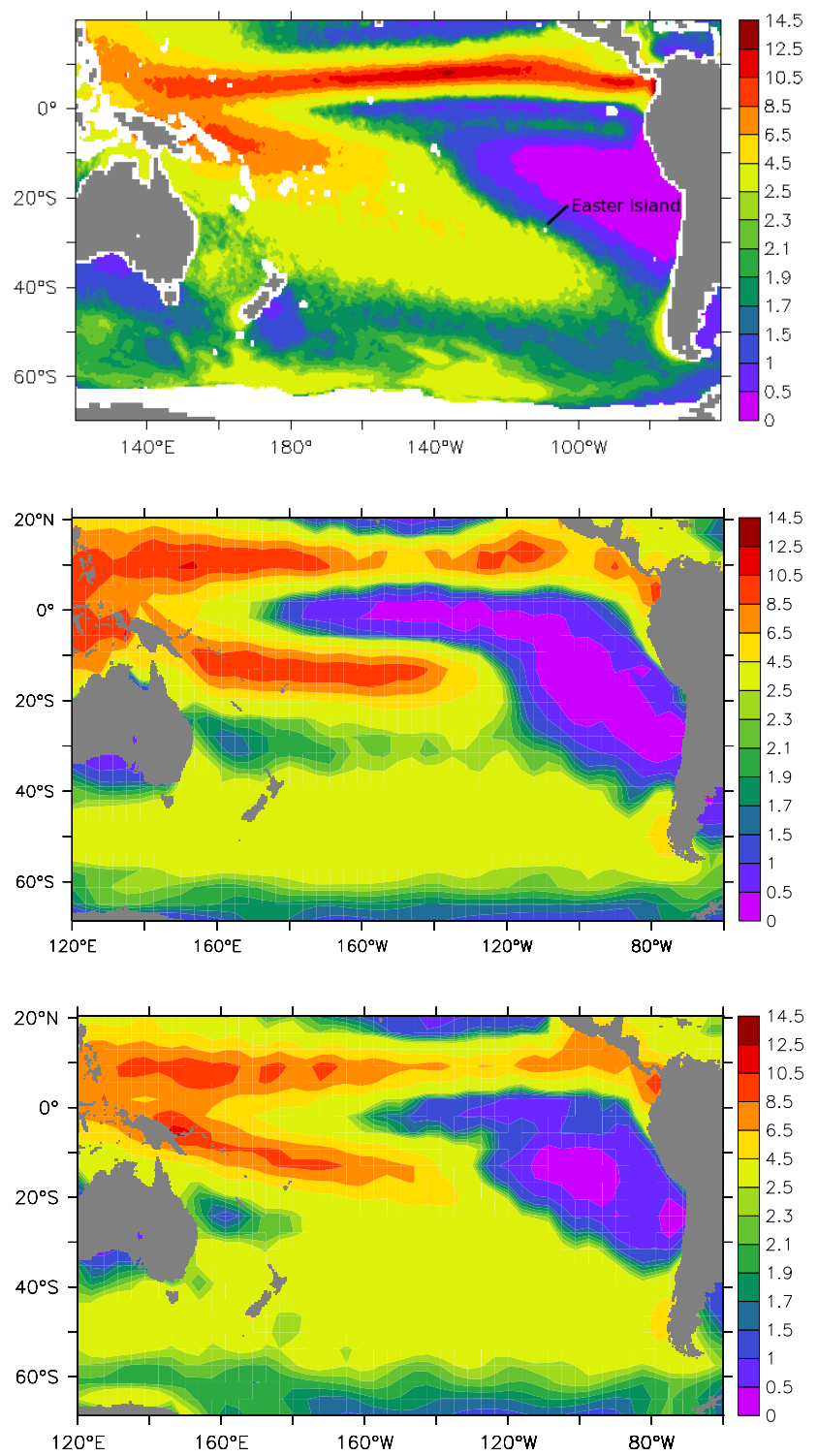

Fig. 1. Climatological mean of the precipitation rates $[\mathrm{mm} / \mathrm{d}]$ in the Pacific region: (top) HOAPS-3 data for the period 1987-2005, (middle) ensemble mean of the Millennium experiments mil0010, mil0012 and mil0013 for the period 1987-2005, (bottom) ensemble mean of the ECHO-G experiments Erikl and Erik2 for the period 1972-1990.

\section{Analysis of model results}

To explore possible climate changes on Rapa Nui in prehistoric times, we used model results of the past millennium because undisturbed proxies of precipitation and temperature are not available for Rapa Nui. Only very few simulations of the last millennium using comprehensive coupled climate models are available to address this topic (e.g. Ammann et al., 2007; Servonnat et al., 2010; Swingedouw et al., 2010). Therefore, the following analyses of the millennium ensemble simulations with the comprehensive Earth system models ECHAM5/MPIOM (Jungclaus et al., 2010) and ECHO-G (González-Rouco et al., 2006) are an important contribution for understanding pre-industrial climate variability in the Pacific region.

\subsection{Ensemble simulations with ECHAM/MPIOM}

First, we analysed model results from the Millennium project coordinated by the Max Planck Institute for Meteorology (Jungclaus et al., 2010). The millennium simulations with a fully interactive carbon cycle were carried out with the MPI Earth system model ECHAM5/MPIOM, consisting of the atmosphere model ECHAM5 (Roeckner et al., 2003) run at $\mathrm{T} 31$ resolution (horizontal resolution of $\sim 3.75^{\circ} \times 3.75^{\circ}$ ) with 19 vertical layers and the ocean model MPIOM (Marsland et al., 2003) with a horizontal resolution ranging from $22 \mathrm{~km}$ to $350 \mathrm{~km}$. The carbon cycle model comprises the land surface scheme JSBACH and the ocean biogeochemistry module HAMOCC5 (Jungclaus et al., 2010).

The ensemble simulations carried out with ECHAM5/ MPIOM reproduce the pre-industrial temperature variability consistent with the range of reconstructions (Jungclaus et al., 2010). The evaluation of a 300-yr control simulation with ECHAM5/MPIOM already showed that the tropical sea surface temperature climatology is well simulated and that global-scale heat and freshwater-transport are in agreement with observations (Jungclaus et al., 2006). Furthermore, ECHAM5/MPIOM has been successfully applied to different paleoclimate states such as Mid-Holocene climate and transient Holocene climate simulations (Fischer and Jungclaus, 2010; Otto et al., 2009; Dallmeyer et al., 2010; Vamborg et al., 2011), Last Glacial Maximum simulations (Mikolajewicz, 2011; Arpe et al., 2011), Eemian climate simulations (Fischer and Jungclaus, 2010; Schurgers et al., 2006) and Eocene climate simulations (Heinemann et al., 2009).

For this study we use the control run mil0001 with constant climate forcing and the ensemble members mil0010, mil0012 and mil0013 with time dependent forcings such as the varying solar irradiance and volcanic activity (Jungclaus et al., 2010). The climatological precipitation rates (19872005) for the tropical and South Pacific from the ensemble mean are shown in Fig. 1 (middle). We argue that in comparison to the HOAPS-3 climatology, ECHAM5/MPIOM reproduces the ITCZ well and reveals the typical pattern of the SPCZ and the eastern Pacific dry zone. However, the location of the SPCZ in the model deviates from the observation such that the area under consideration is just outside the range of the SPCZ due to a more zonally orientated SPCZ in the model. Therefore, ECHAM5/MPIOM tends to underestimate precipitation in the region around Rapa Nui. The climatological precipitation rate (1987-2005) around Rapa Nui is $\sim 1.5 \mathrm{~mm} \mathrm{~d}^{-1}\left(\sim 547.5 \mathrm{~mm} \mathrm{yr}^{-1}\right)$ which is $25 \%$ less compared to the satellite-based estimates. 

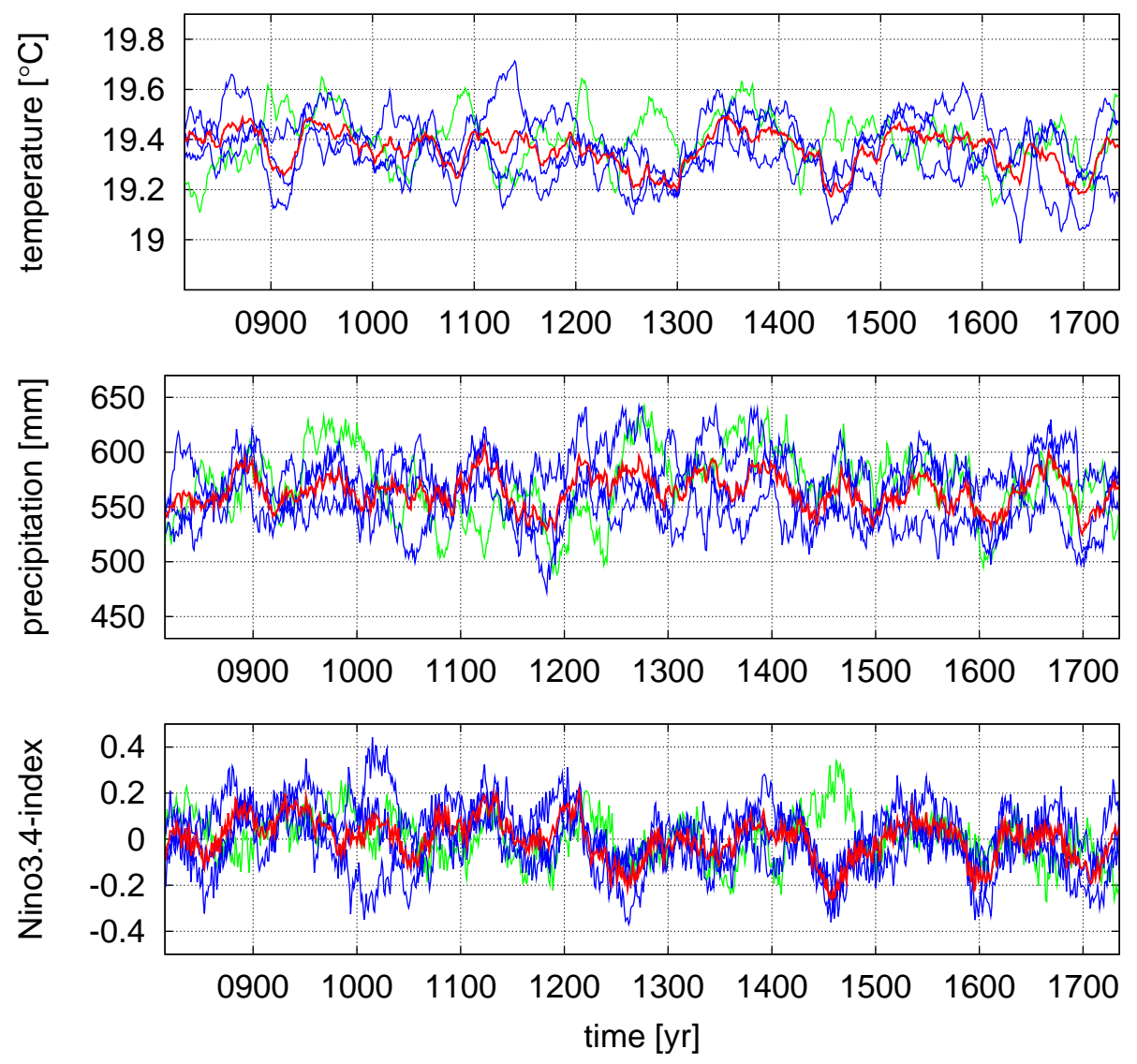

Fig. 2. 30-year running mean of simulated near-surface air temperature (top), precipitation (middle) and Niño3.4-index (bottom) around Rapa Nui for the period 800-1750 AD. Shown are the Millennium experiments mil0001 (green), the ensemble members mil0010, mil0012 and mil0013 (blue) and the ensemble mean (red).

To test the model results for climatic trends for the period $800-1750 \mathrm{AD}$, we selected the near-surface air temperature and precipitation for the grid point covering Rapa Nui and calculated a 30-year running climate mean for this period. The timeseries of the control and ensemble simulations (Fig. 2) do not show any significant trend for the given period. A closer look at all eight grid cells surrounding the grid cell encompassing Rapa Nui (not shown here) confirms the result for the grid cell covering Rapa Nui: there are no significant trends in precipitation or temperature in any of these grid cells. Therefore, the model results do not corroborate the assumption of Nunn (2000) that a temperature decrease associated with a large-scale cooling from the Medieval period to the Little Ice Age and an associated precipitation change could have influenced the climate on Rapa Nui around $1300 \mathrm{AD}$. Likewise, a cool and dry MWP and comparatively warm and relatively wet LIA as seen in paleoclimate reconstructions for the central Pacific (Allen, 2006) cannot be found for the region around Rapa Nui in the model results.

To investigate the influence of the ENSO phenomenon on the climate of Rapa Nui during the last millennium, we calculated the correlations between the simulated time series of the Niño3.4-index and the simulated timeseries of near-surface air temperature and precipitation as suggested by Genz and Hunt (2003). The Niño3.4-index can be obtained by selecting the sea surface temperature (SST) for the tropical Pacific between $120^{\circ} \mathrm{W}-170^{\circ} \mathrm{W}$ and $5^{\circ} \mathrm{N}-5^{\circ} \mathrm{S}$ from the model results and calculating the SST anomalies as well as a 5-month running mean. A trend analysis of the timeseries of the Niño3.4-index confirmed that there is no climatic trend in the SST anomalies. The empirical correlation between the Niño3.4-index and the near-surface air temperature on Rapa Nui is $r=0.421$, and between the Niño3.4-index and the precipitation $r=0.282$. We conclude that there is no significant correlation between the ENSO-phenomenon and the climate variability near Rapa Nui in the model which is in line with earlier analyses for present-day climate (MacIntyre, 2001a,b).

Around $1258 \mathrm{AD}$, a strong volcanic eruption occurred in the tropics. According to Oppenheimer (2003), ice cores from both the Antarctic and the Arctic indicate a volcanic eruption at that time which could have been the strongest of the last millennium. The ensemble simulations mil0010, 


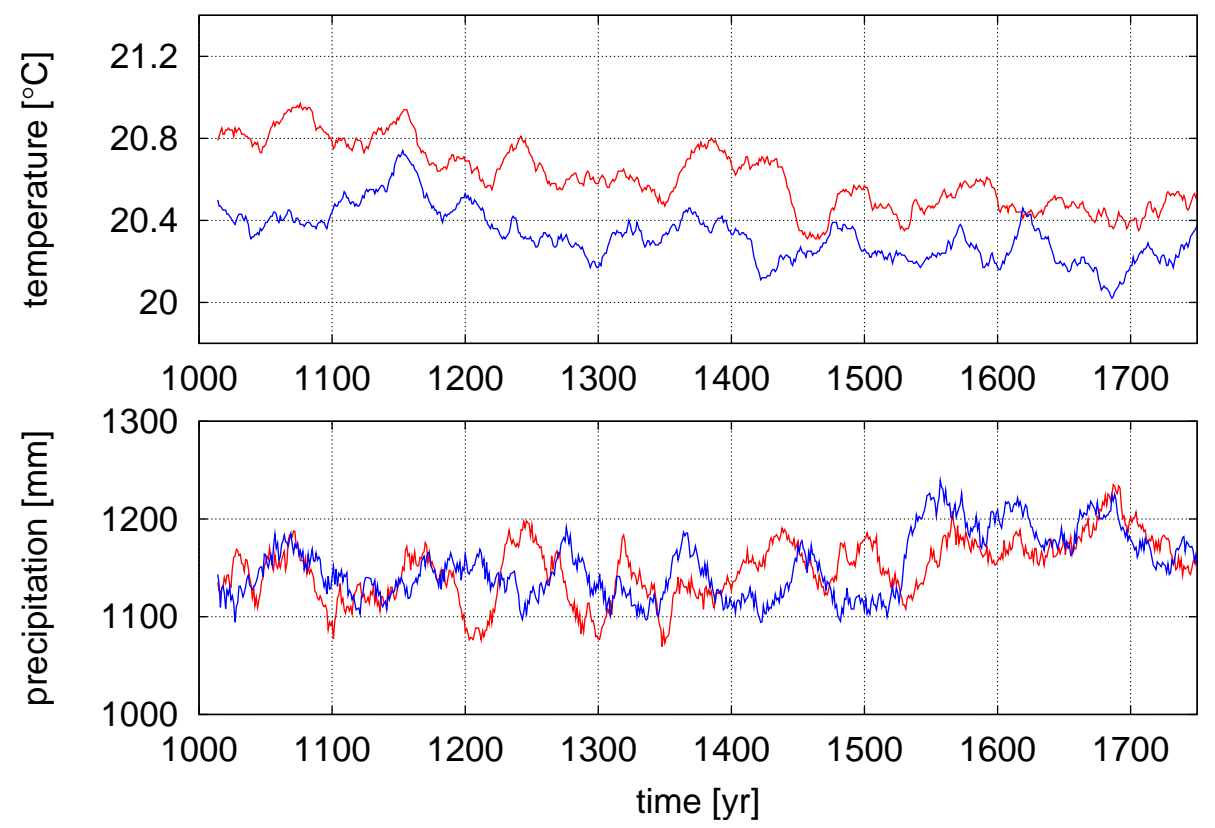

Fig. 3. 30-year running mean of simulated near-surface air temperature (top) and precipitation (bottom) for the period 1000-1750 AD. Shown are the ensemble simulations Erik1 (red) and Erik2 (blue) conducted with the atmosphere-ocean model ECHO-G.

mil0012 and mil0013 include the effect of this volcanic eruption (as well as other reconstructed eruptions during the last millennium) on the atmospheric radiation and energy budget. While the impact of the eruption in $1258 \mathrm{AD}$ is clearly seen in global and hemispheric mean temperature values in the model, hardly any change can be detected for the region near Rapa Nui.

\subsection{Ensemble simulations with ECHO-G}

The model results from the ensemble simulations of the ECHAM5/MPIOM model show only small climatic trends from the Medieval Warm Period to the Little Ice Age in global mean temperature, in general, although some members of the simulation ensemble do capture the amplitude between MWP and LIA temperatures. Therefore, we analysed two ensemble simulations (Erikl and Erik2) with an earlier version of the model system, referred to as ECHO$\mathrm{G}$, consisting of the atmosphere model ECHAM4 run at T30 resolution (horizontal resolution of $\sim 3.75^{\circ} \times 3.75^{\circ}$ ) coupled to the ocean model HOPE-G run at T42 resolution $\left(\sim 2.8^{\circ}\right)$ with grid refinement at low latitudes for the ocean (GonzálezRouco et al., 2006). The simulations with this model system reveal a strong decrease of around $1.25^{\circ} \mathrm{C}($ Erikl $)$ and $0.75^{\circ} \mathrm{C}$ (Erik2) in the $2 \mathrm{~m}$-temperature (González-Rouco et al., 2006) from the MWP to the LIA for the Northern Hemisphere. This might be an unrealistically strong global cooling trend according to most reconstructions (IPCC, 2001).

Earlier studies with ECHO-G found that broad patterns of global temperature variability are well captured by the model compared with reconstructions (Zorita et al., 2004; 2005). Furthermore, ECHO-G reasonably simulates ENSO structures (like the tropical SST climate), atmospheric responses to ENSO and the subsurface ocean behaviour such as equatorial Kelvin and off-equatorial Rossby waves (Min et al., 2005). In addition, ECHO-G has been successfully applied to paleoclimate states such as Last Interglacial simulations (Felis et al., 2004) and Holocene simulations (Kim et al., 2004; Rimbu et al., 2004).

To evaluate the ability of the model to simulate the typical pattern in the tropical and South Pacific, we show the precipitation climatology from the ensemble mean of the simulations Erik1 and Erik2 for the period 1972-1990 in Fig. 1 (bottom). Since the ECHO-G simulations were not extended beyond 1990, we have to tentatively compare the ECHO-G climatology (1972-1990) with the HOAPS-3 and ECHAM5/MPIOM climatology (1987-2005). As for ECHAM5/MPIOM, ECHO-G reproduces the ITCZ well and reveals the typical pattern of the SPCZ and the East Pacific dry zone. However, ECHO-G tends to overestimate the precipitation around Rapa Nui, since the SPCZ reaches further southeastwards in this model. Therefore, the climatological precipitation rate around Rapa Nui is roughly $3 \mathrm{~mm} \mathrm{~d}^{-1}$ (1095 $\mathrm{mm} \mathrm{yr}^{-1}$ ) which is $\sim 50 \%$ higher than the HOAPS-3 climatological precipitation.

To test the model results for climatic trends for the period $800-1750 \mathrm{AD}$, a 30 -year running mean of near-surface air temperature and precipitation is depicted in Fig. 3 for the ensemble simulations Erikl and Erik2 for the the grid point covering Rapa Nui. Both simulations with ECHO-G show 
a temperature decrease between the 12 th and the 15 th century, but the cooling trend of some $-0.4{ }^{\circ} \mathrm{C}$ for the region of Rapa Nui is much weaker than the (simulated) Northern Hemispheric cooling trend (González-Rouco et al., 2006). The simulated precipitation remains at a nearly constant but high level until $1500 \mathrm{AD}$, with a yearly mean precipitation of about $1150 \mathrm{~mm}$ (Fig. 3). After around $1500 \mathrm{AD}$, a small but significant increase in simulated precipitation can be detected. Furthermore, the trends in the eight grid cells surrounding the grid cell of Rapa Nui (not shown here) confirm the result for the grid cell covering Rapa Nui.

\section{Sensitivity simulations with the BIOME-1.0 model}

To tentatively explore possible effects of simulated climate variability on the vegetation of Rapa Nui, we carried out sensitivity simulations by using the model BIOME-1.0 (Prentice et al., 1992). BIOME-1.0, like its more recent version BIOME-4, is a model for global application. It is not specifically tuned to vegetation on sub-tropical islands. However, it captures the boundaries between tropical forests and grassland reasonably well. Therefore, we think this model can be used for a first tentative estimate of possible drastic changes between forest and grassland. As input variables for BIOME-1.0, near-surface air temperature, precipitation and cloud fraction are derived from the ensemble simulations mil0010, mil0012 and mil0013. The mean annual cycle of the simulated climate variables around Rapa Nui were calculated for the period 800-1750 AD. Because the model precipitation from the Millennium experiments (around $550 \mathrm{~mm} \mathrm{yr}^{-1}$ ) is much lower than observed local precipitation (around $1100 \mathrm{~mm} \mathrm{yr}^{-1}$ ), we added the difference between model results and observational data to the annual cycle of precipitation and increased the cloud fraction by 0.1 .

First, the simulated climatology was varied within the range of simulated decadal fluctuations of the ensemble simulations, and these values were used as input for the BIOME 1.0 model. In a second set of sensitivity simulations, the values of the water holding capacity (watc) in the BIOME model was varied between $50-350 \mathrm{~mm}$ with the climatology held constant. This range of values of watc was chosen to represent the spatial variability in the soil-water capacity on Rapa Nui between soils with very low water holding capacities around $50 \mathrm{~mm}$ (Leptosols) and soils with water capacities exceeding $300 \mathrm{~mm}$ (Anthrosols) (personal communication with H.-R. Bork, unpublished data, 2009). Finally, we tested the sensitivity of the BIOME 1.0 model results to climate changes stronger than our climate simulations indicate. Hence, we prescribed a cooling trend of some $1{ }^{\circ} \mathrm{C}$ which presumably is as large as the temperature difference between present-day climate and the climate around the Last Glacial Maximum (LGM) for the Southeast Pacific area (Ganopolski et al., 1998; Braconnot et al., 2007;
MARGO Project Members, 2009). In all cases, the BIOME model computes forest coverage, either as warm-temperate evergreen forests or tropical raingreen or tropical evergreen forests. No shifts to shrub or grassland were found in the simulations.

\section{Conclusions}

Climate simulations with two different climate models have been analysed with respect to simulated temperature and precipitation in the region around Rapa Nui between 800 and $1750 \mathrm{AD}$. The climate models represent present-day global climate patterns and climate variability reasonably well. They agree with each other in many respects, but they also differ. The models represent the location and strength of the SPCZ differently: one model tends to simulate less rainfall than reconstructed for the region around Rapa Nui, while the other tends to overestimate rainfall. One model produces a weak global and northern hemispheric mean cooling from the Warm Medieval Period towards the Little Ice Age, while the other model reveals a strong trend in comparison with reconstructions. Both models reveal a clear response of global and regional climate to the strong volcanic eruption around 1258 AD. Despite these differences, both models show qualitatively similar results with respect to long-term climate change near Rapa Nui: they either reveal no statistically significant or marginally small trends in simulated temperature and precipitation. Furthermore, no strong climate change over Rapa Nui, in response to the strong volcanic eruption around $1258 \mathrm{AD}$, has been seen in the models.

Some first, very preliminary sensitivity studies on the effect of (simulated) climate variations on the vegetation change indicate no significant change in forest coverage on Rapa Nui. Hence, we tentatively conclude that large-scale climate changes in the region of Rapa Nui might be too small to explain strong vegetation changes on the island over the last millennium. We cannot exclude, however, small-scale, local effects on precipitation over the island in response to changes in the local atmosphere-ecosystem system of the island.

Acknowledgements. The authors thank Rainer Schnur for providing the datasets of the ECHAM5/MPIOM model, Axel Andersson for discussing the HOAPS-3 data and Eduardo Zorita for providing and discussing the datasets of the ECHO-G model. We are grateful to Hans-Rudolf Bork for motivating discussions and valuable information about Rapa Nui and to Johann Jungclaus and Erich Roeckner for providing information about the evaluation of ECHAM5. The suggestions made by the editor Ed Brook, three anonymous reviewers and Pavel Tarasov improved the quality of manuscript.

Edited by: E. Brook 


\section{References}

Allen, M. S.: New Ideas about Late Holocene Climate Variability in the Central Pacific, Curr. Anthropol., 47(3), 521-535, 2006.

Ammann, C., Joos, F., Schimel, D., Otto-Bliesner, B., and Tomas, R.: Solar influence on climate during the past millennium: Results from transient simulations with the NCAR Climate System Model, P. Natl. Acad. Sci., 104, 3713-3718, 2007.

Andersson, A., Bakan, S., Fennig, K., Grassl, H., Klepp, C.P., and Schulz, J.: Hamburg Ocean Atmosphere Parameters and Fluxes from Satellite Data - HOAPS-3 monthly mean, World Data Center for Climate, 3097, doi:10.1594/WDCC/HOAPS3_MONTHLY, 2007.

Andersson, A., Klepp, C., Fennig, K., Bakan, S., Grassl, H., and Schulz, J.: Evaluation of HOAPS-3 Ocean Surface Freshwater Flux Components, J. Appl. Meteorol. Clim., 50, 379-398, 2011.

Arpe, K., Leroy, S. A. G., and Mikolajewicz, U.: A comparison of climate simulations for the last glacial maximum with three different versions of the ECHAM model and implications for summer-green tree refugia, Clim. Past, 7, 91-114, doi:10.5194/cp-7-91-2011, 2011.

Braconnot, P., Otto-Bliesner, B., Harrison, S., Joussaume, S., Peterchmitt, J.-Y., Abe-Ouchi, A., Crucifix, M., Driesschaert, E., Fichefet, Th., Hewitt, C. D., Kageyama, M., Kitoh, A., Laîné, A., Loutre, M.-F., Marti, O., Merkel, U., Ramstein, G., Valdes, P., Weber, S. L., Yu, Y., and Zhao, Y.: Results of PMIP2 coupled simulations of the Mid-Holocene and Last Glacial Maximum Part 1: experiments and large-scale features, Clim. Past, 3, 261277, doi:10.5194/cp-3-261-2007, 2007.

Dallmeyer, A., Claussen, M., and Otto, J.: Contribution of oceanic and vegetation feedbacks to Holocene climate change in monsoonal Asia, Clim. Past, 6, 195-218, doi:10.5194/cp-6-1952010, 2010.

Felis, T., Lohmann, G., Kuhnert, H., Lorenz, S., Scholz, D., Pätzold, J., Al-Rousan, S., and Al-Moghrabi, S.: Increased seasonality in Middle East temperatures during the last interglacial period, Nature, 429, 164-168, 2004.

Fischer, N. and Jungclaus, J. H.: Effects of orbital forcing on atmosphere and ocean heat transports in Holocene and Eemian climate simulations with a comprehensive Earth system model, Clim. Past, 6, 155-168, doi:10.5194/cp-6-155-2010, 2010.

Flenley, J. R. and Bahn, P.: The Enigmas of Easter Island, University Press, Oxford, 2003.

Flenley, J. R. and King, A. S.: Late quaternary pollen records from Easter Island, Nature, 307, 47-50, 1984.

Flenley, J. R., King, A. S. M., Teller, J. T., Prentice, M. E., Jackson, J., and Chew, C.: The late quaternary vegetational and climatic history of Easter Island, J. Quaternary Sci., 6, 85-115, 1991.

Ganopolski, A., Rahmstorf, S., Petoukhov, V., and Claussen, M.: Simulation of modern and glacial climates with a coupled global model of intermediate complexity, Nature, 391, 351-356, 1998.

Genz, J. and Hunt, T. L.: El Niño Oscillation and Rapa Nui prehistory, Rapa Nui J., 17(1), 7-14, 2003.

González-Rouco, J., Beltrami, H., Zorita, E., and Von Storch, H.: Simulation and inversion of borehole temperature profiles in surrogate climates: Spatial distribution and surface coupling, Geophys. Res. Lett., 33, L01703, doi:10.1029/2005GL024693, 2006.
Heinemann, M., Jungclaus, J. H., and Marotzke, J.: Warm Paleocene/Eocene climate as simulated in ECHAM5/MPI-OM, Clim. Past, 5, 785-802, doi:10.5194/cp-5-785-2009, 2009.

Hunt, T. L.: Rethinking Easter Island's ecological catastrophe, J. Archaeol. Sci., 34, 485-502, 2006.

Hunt, T. L. and Lipo, C. P.: Late colonization of Easter Island, Science, 311, 1603-1606, 2006.

IPCC: Climate Change 2001: The Scientific Basis, Contribution of Working Group I to the Third Assessment Report of the Intergovernmental Panel on Climate Change, edited by: Houghton, J. T., Ding, Y., Griggs, D. J., Noguer, M., van der Linden, P. J., Dai, X., Maskell, K., and Johnson, C. A., Cambridge University Press, Cambridge and New York, NY, 881 pp., 2001.

Jungclaus, J., Keenlyside, N., Botzet, M., Haak, H., Luo, J., Latif, M., Marotzke, J., Mikolajewicz, U., and Roeckner, E.: Ocean circulation and tropical variability in the coupled model ECHAM5/MPI-OM, J. Climate, 19, 3952-3972, 2006.

Jungclaus, J. H., Lorenz, S. J., Timmreck, C., Reick, C. H., Brovkin, V., Six, K., Segschneider, J., Giorgetta, M. A., Crowley, T. J., Pongratz, J., Krivova, N. A., Vieira, L. E., Solanki, S. K., Klocke, D., Botzet, M., Esch, M., Gayler, V., Haak, H., Raddatz, T. J., Roeckner, E., Schnur, R., Widmann, H., Claussen, M., Stevens, B., and Marotzke, J.: Climate and carbon-cycle variability over the last millennium, Clim. Past, 6, 723-737, doi:10.5194/cp-6723-2010, 2010.

Kim, J., Rimbu, N., Lorenz, S., Lohmann, G., Nam, S., Schouten, S., Rühlemann, C., and Schneider, R.: North Pacific and North Atlantic sea-surface temperature variability during the Holocene, Quaternary Sci. Rev., 23, 2141-2154, 2004.

MacIntyre, F.: ENSO, climate variability, and the Rapanui: I. The basics, Rapa Nui J., 15, 17-26, 2001a.

MacIntyre, F.: ENSO, climate variability, and the Rapanui: II. Oceanography and Rapa Nui, Rapa Nui J., 15, 1-28, 2001 b.

Mann, M. E., Cane, M. A., Zebiak, S. E., and Clement, A.: Volcanic and solar forcing of the tropical Pacific over the past 1000 years, J. Climate, 18, 447-456, 2005.

Mann, D., Edwards, J., Chase, J., Warren, B., Reanier, R., Mass, M., Finney, B., and Loret, J.: Drought, vegetation change, and human history on Rapa Nui (Isla de Pascua, Easter Island), Quaternary Res., 69, 16-28, 2008.

MARGO Project Members: Constraints on the magnitude and patterns of ocean cooling at the Last Glacial Maximum, Nat. Geosci., 2, 127-132, 2009.

Marsland, S., Haak, H., Jungclaus, J., Latif, M., and Roske, F.: The Max-Planck-Institute global ocean/sea ice model with orthogonal curvilinear coordinates Ocean Modelling, Elsevier, 5, 91-127, 2003.

Martinsson-Wallin, H. and Crockford, S. J.: Early settlement of Rapa Nui (Easter Island), Asian Perspect., 40, 244-278, 2001.

Mieth, A. and Bork, H.-R.: History, origin and extent of soil erosion on Easter Island (Rapa Nui), Catena, 63, 244-260, 2005.

Mieth, A. and Bork, H.-R.: Wandel eines isolierten Lebensraumes: wiey Landnutzung die Lebensbedingungen auf der Osterinsel (Südpazifik, Chile) veränderte, Nova Act. Lc., 94(346), 157-172, 2006.

Mikolajewicz, U.: Modeling Mediterranean Ocean climate of the Last Glacial Maximum, Clim. Past, 7, 161-180, doi:10.5194/cp7-161-2011, 2011. 
Min, S., Legutke, S., Hense, A., and Kwon, W: Internal variability in a $1000-y r$ control simulation with the coupled model ECHOG: Near-surface temperature, precipitation and mean sea level pressure, Tellus, 605-621, 2005.

Nunn, P. D.: Environmental catastrophe in the Pacific Islands around AD 1300, Geoarchaeology, 15(7), 715-740, 2000.

Oppenheimer, C.: Ice core and palaeoclimatic evidence for the timing and nature of the great mid-13th century volcanic eruption, Int. J. Climatol., 23, 417-426, 2003.

Orliac, C. and Orliac, M.: The disappearance of Easter Island's forest: over-exploitation or climatic catastrophe?, in: Easter Island in Pacific Context, edited by: Stevenson, C. M., Lee, G., and Morin, F. J., South Seas symposium, Proceedings of the Fourth International Conference on Easter Island and East Polynesia, Easter Island Foundation, 4, 129-144, 1997.

Otto, J., Raddatz, T., Claussen, M., Brovkin, V., and Gayler, V.: Separation of atmosphere-ocean-vegetation feedbacks and synergies for mid-Holocene climate, Geophys. Res. Lett., 36, L09701, doi:10.1029/2009GL037482, 2009.

Prentice, I. C., Cramer, W., Sandy, P. H., Leemans, R., Monserud, R. A., and Solomon, A. M.: A global biome model based on plant physiology and dominance, soil properties and climate, J. Biogeogr., 19, 117-134, 1992.

Rimbu, N., Lohmann, G., Lorenz, S., Kim, J., and Schneider, R.: Holocene climate variability as derived from alkenone sea surface temperature and coupled ocean-atmosphere model experiments, Clim. Dynam., 23, 215-227, 2004.

Roeckner, E., Bäuml, G., Bonaventura, L., Brokopf, R., Esch, M., Giorgetta, M., Hagemann, S., Kirchner, I., Kornblueh, L., Manzini, E., Rhodin, A., Schlese, U., Schulzweida, U., and Tompkins, A.: The atmospheric general circulation model ECHAM 5, PART I: Model description, Max Planck Institute for Meteorology Rep. 349, available from MPI for Meteorology, Bundesstr. 53, 20146 Hamburg, Germany, 2003.

Rolett, B. and Diamond, J.: Environmental predictors of preEuropean deforestation on Pacific islands, Nature, 431, 443-446, 2004.
Saez, A., Valero-Garces, B. L., Giralt, S., Moreno, A., Bao, R., Pueyo, J. J., Hernandez, A., and Casas, D.: Glacial to Holocene climate changes in the SE Pacific, the Raraku Lake sedimentary record (Easter Island, $27^{\circ} \mathrm{S}$, Quaternary Sci. Rev., 28, 27432759, 2009.

Schurgers, G., Mikolajewicz, U., Gröger, M., Maier-Reimer, E., Vizcaíno, M., and Winguth, A.: Dynamics of the terrestrial biosphere, climate and atmospheric $\mathrm{CO}_{2}$ concentration during interglacials: a comparison between Eemian and Holocene, Clim. Past, 2, 205-220, doi:10.5194/cp-2-205-2006, 2006.

Servonnat, J., Yiou, P., Khodri, M., Swingedouw, D., and Denvil, S.: Influence of solar variability, $\mathrm{CO}_{2}$ and orbital forcing between 1000 and 1850 AD in the IPSLCM4 model, Clim. Past, 6, 445-460, doi:10.5194/cp-6-445-2010, 2010.

Swingedouw, D., Terray, L., Cassou, C., Voldoire, A., SalasMélia, D., and Servonnat, J.: Natural forcing of climate during the last millennium: fingerprint of solar variability, Clim. Dynam., 36, 1349-1364, 2011.

Vamborg, F. S. E., Brovkin, V., and Claussen, M.: The effect of a dynamic background albedo scheme on Sahel/Sahara precipitation during the mid-Holocene, Clim. Past, 7, 117-131, doi:10.5194/cp-7-117-2011, 2011.

Vincent, D. G.: The South Pacific Convergence Zone (SPCZ): a review, Mon. Weather Rev., 122, 1949-1970, 1993.

Wilmshurst, J., Hunt, T., Lipo, C., and Anderson, A.: Highprecision radiocarbon dating shows recent and rapid initial human colonization of East Polynesia, P. Natl. Acad. Sci., 108, 1815-1820, 2011.

Zorita, E., Von Storch, H., Gonzalez-Rouco, F., Cubasch, U., Luterbacher, J., Legutke, S., Fischer-Bruns, I., and Schlese, U.: Climate evolution in the last five centuries simulated by an atmosphere-ocean model: global temperatures, the North Atlantic Oscillation and the Late Maunder Minimum, Meteorol. Z., 13, 271-289, 2004.

Zorita, E., Gonzalez-Roucho, J. F., von Storch, H., Montavez, J. P., and Valero, F.: Natural and anthropogenic modes of surface temperature variations in the last thousands years, Geophys. Res. Lett., 32, L08707, doi:10.1029/2004GL021563, 2005. 